\title{
The Tegumental Glands of a Troglobitic Crustacean
}

\author{
by
}

\author{
L. JUBERTHIE-JUPEAU and Y. CROUAU*
}

\section{INTRODUCTION}

An attempt of a complete study of antennae of a Crustacea Mysidacea Antromysis juberthiei Bacesco et Orghidan has been undertaken and leads us to investigate the tegumental glands located in these appendages. Similar glands are probably present in other parts of the animal, both in males and females; as we have been able to see after the ecdysis, canals very similar to those present in the glands of the antennae remain attached to the old cuticle in different parts of the body such as abdomen, telson and uropodes.

As far as Mysidacea are concerned the tegumentary glands were unknown, only the digestive glands were described by Gelderd (1909). In other Crustaceans many tegumental glands associated with the cuticle have been described (Yonge 1932, Radu et al. 1942, Gorvett 1946, 1951, 1952, 1956, Patané 1955, Maccagno-Paulucci 1957, Fahrenbach 1961, Messner 1963, Stevenson 1964, Park 1966, Cals et al. 1971, Pochon-Masson et al. 1975), but only a few of them have been studied with the electron microscope.

\section{MATERIALS AND METHODS}

The studied Mysidacea belongs to a troglobitic species Antromysis juberthiei Bacesco and Orthidan. The animals collected in Cuba (Pinos Island) by C. Juberthie and N. Vina in 1974 were bred in the laboratory; the antennulae were removed from Mysidacea collected in C period; the exopodites were fixed in $2.9 \%$ glutaraldehyde in $0.15 \mathrm{M}$ Millonig buffer and post-fixed in $1 \% \mathrm{OsO}_{4}$ in the same buffer. Sections were cut with a diamond knife on a Reichert $\mathrm{OMU}_{2}$ ultratome and contrast was enhanced with uranyl acetate and lead citrate. Sections were examined in a Sopelem electron microscope operated at $50 \mathrm{kv}$.

1) Laboratoire souterrain du Centre National de la Recherche Scientifique, 09410 Moulis, France. 


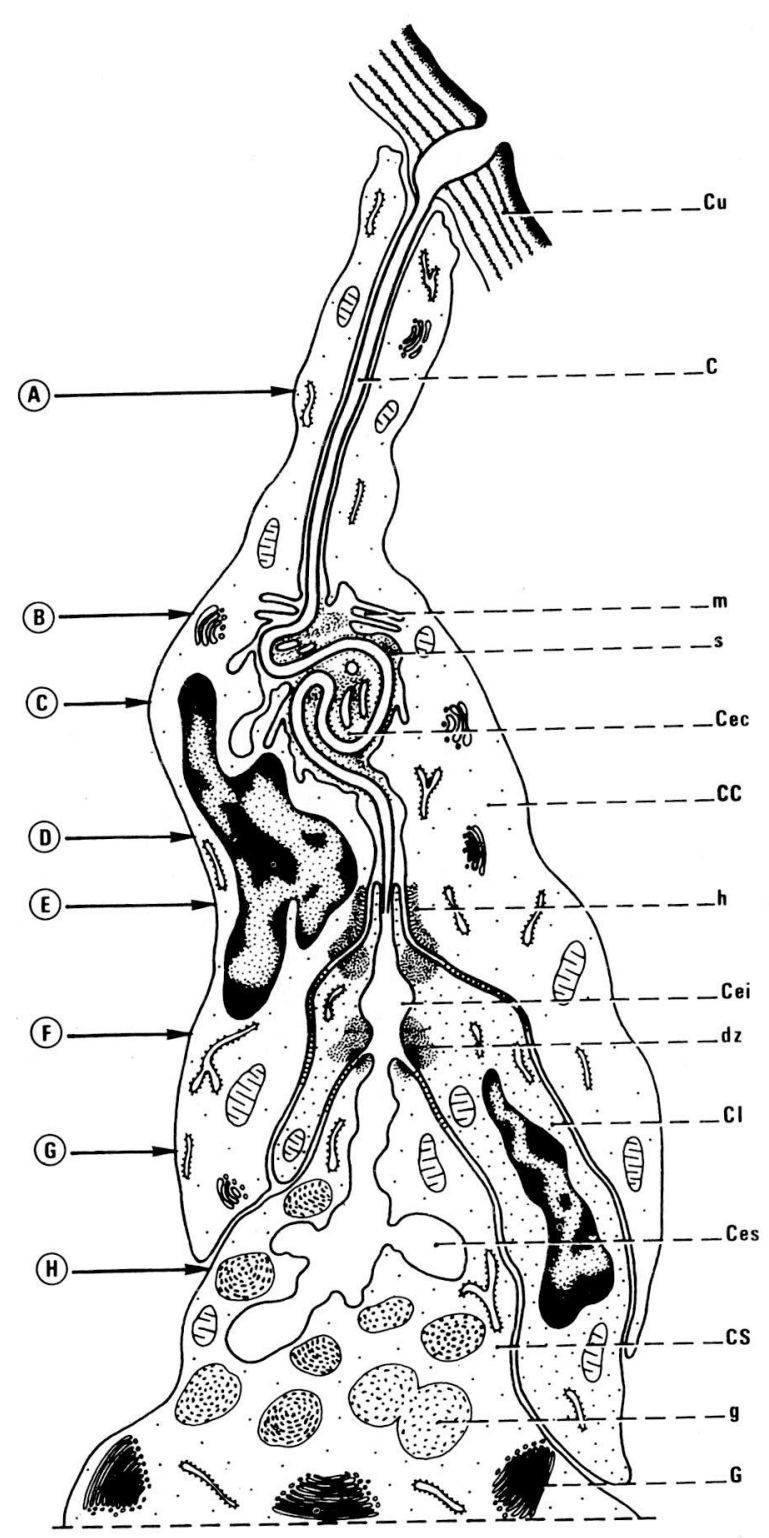

Fig. 1. Diagram of a longitudinal section in the upper part of a gland; $\mathrm{C}$, canal; $\mathrm{CC}$, canal cell; $\mathrm{Cec}$, extracellular cavity of the canal cell; Cei, extracellular cavity of the intermediary cell; Ces, extracellular cavity of the secretory cell; CI, intermediary vell; CS, secretory cell; $\mathrm{Cu}$, cuticule with the hollow where the canal opens; d.z., zonular desmosome; G, Golgi apparatus; g. secretory granules; $h$, hemidesmosome; $m$. microvilli; $s$, secretion in the cavity of the canal cell; A, B, C, D, E, F, G, H. indicate the level of sections of Fig. 2. 
(A)

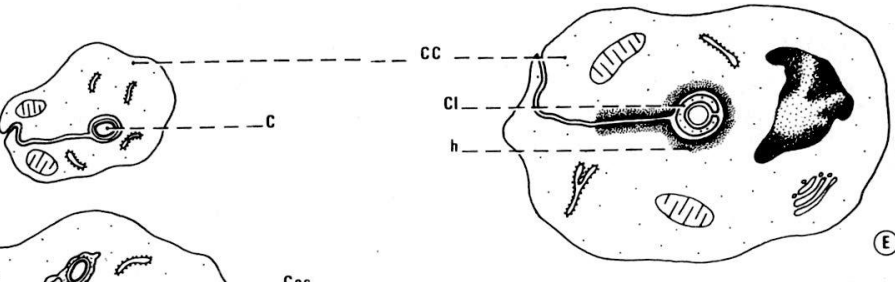

(B)
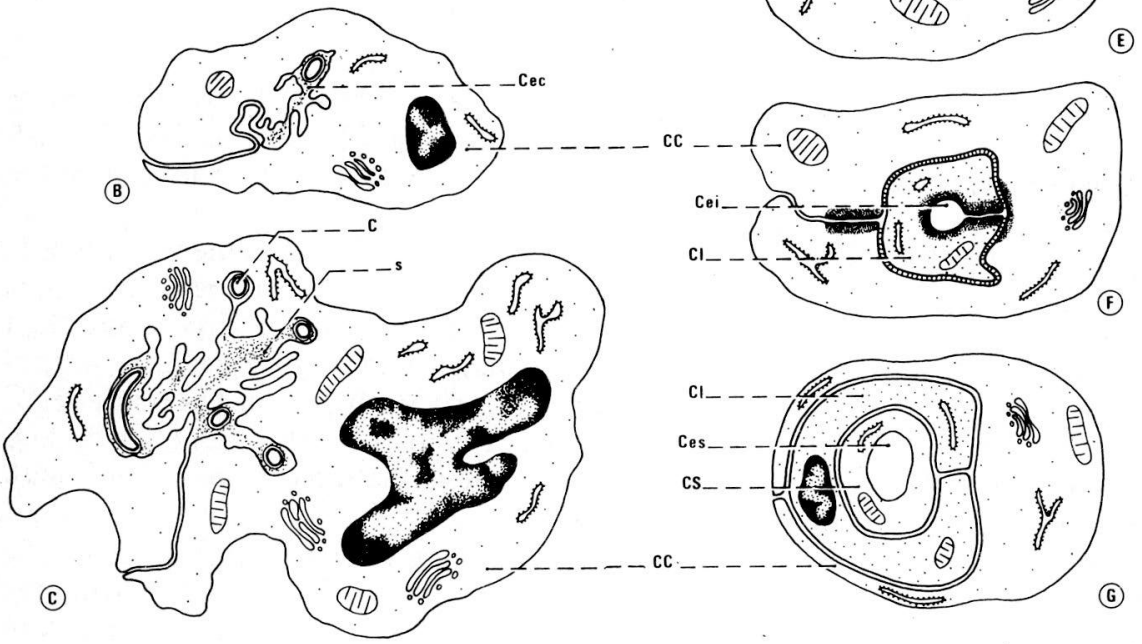

(6)

(D)
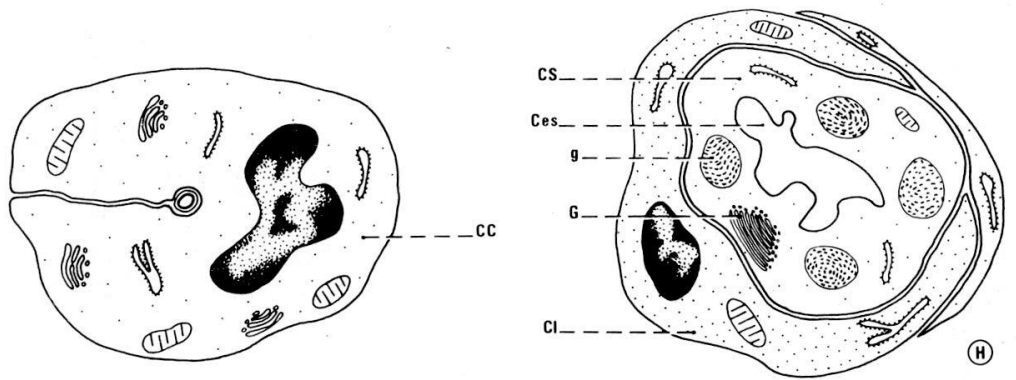

Fig. 2. Transverse sections in the upper part of the gland at the A, B, C, D, E, F, G, H levels. Same abbreviations as Fig. 1.

\section{LOCALIZATION OF GLANDS IN THE ANTENNAE}

The tegumental glands are located in the sympodite and in the flagellum. In the antennulae there are about 20 glands in the exopodite. This one bears sensory hairs of different types in the internal part with respect to the median plane of the animal, the most conspicuous of which being the aesthetasc hairs which display the fine structure of chemoreceptors (Juberthie-Jupeau and Crouau 1977). In every two articles is a tegumental gland in the diametrically opposite part of the aesthetasc. The bulky secretory part occupies almost the whole 
length of an article and the gland opens into a hollow in the cuticle, in the middle of the next article. The secretory cells are situated under the epidermal tissue, and they are in contact with the hemolymph cavity of the antennulae and the longitudinal nervous fibers which run under the epidermis.

\section{FINE STRUCTURE}

Each gland consists of 3 cells (Fig. 1, 2): one secretory cell, surrounded in its distal part by one intermediary cell, surrounded itself by one canal cell which ensheaths its apical part and contains the canal that opens into hollow in the cuticle.

1 - Secretory cell (Fig. 9-11). This cell lies on a thin basal membrane only in its part in contact with the hemolymphatic cavity. This cell, pear-shaped, is over $30 \mu$ long and about $10 \mu$ wide; it exhibits in its upper part an invagination of its plasmic membrane which forms the boundaries of an extracellular irregularly shaped cavity. This cavity in which secretory product is stored is not deep.

The nucleus in the lower part of the cell is regularly shaped, subspherical and reaches 3 to $3.5 \mu$ in diameter. The chromatine is scattered in relatively small granules, principally in the central part.

The cytoplasm, which is voluminous, shows the classical cell organelles the most conspicuous among which are the dictyosomes situated in the two lower thirds of the cell. Each Golgi apparatus (Fig. 10) consists of a stack from 18 to 20 cisternae, the diametre of the stack and its height are about 17000 to $20000 \mathrm{~A}^{\circ}$. On the forming face each dictyosome possesses clear cisternae, associated with endoplasmic reticulum. The other cisternae are flatter than the first ones and they are filled with a fluid content that is electron denser; in transversal sections they show constrictions leaving regular spaces between them; at the periphery of the stack there are numerous vesicles the content of which is more or less electron dense. On the maturing face more voluminous, irregularly shaped vesicles, containing a granular substance, coalesce to form the secretory granules.

The granular endoplasmic reticulum is characterized by large flat cisternae

Fig. 3. Longitudinal section of the antennulae showing the secretory cell (CS), the intermediary cell (CI), the canal cell (CC), with its extracellular cavity $(\mathrm{Cec})$ with microvilli $(\mathrm{m})$; C, sections of the canal; Cei, extracellular cavity of the intermediary cell. x 17500 .

Fig. 4. Canal (c) opening in the hollow of the cuticule (Cu). $\times 13000$.

Fig. 5. Transverse section in the upper part of the canal cell. $x 27500$.

Fig. 6. Transverse section in the extracellular cavity of the canal cell; m. microvilli. x 27500 .

Fig. 7. Transverse section in the upper part of the intermediary cell (CI) and in the canal cell (CC) $\mathrm{x} 27500$.

Fig. 8. Longitudinal section in the distal part of the canal cell. $\times 10000$. 


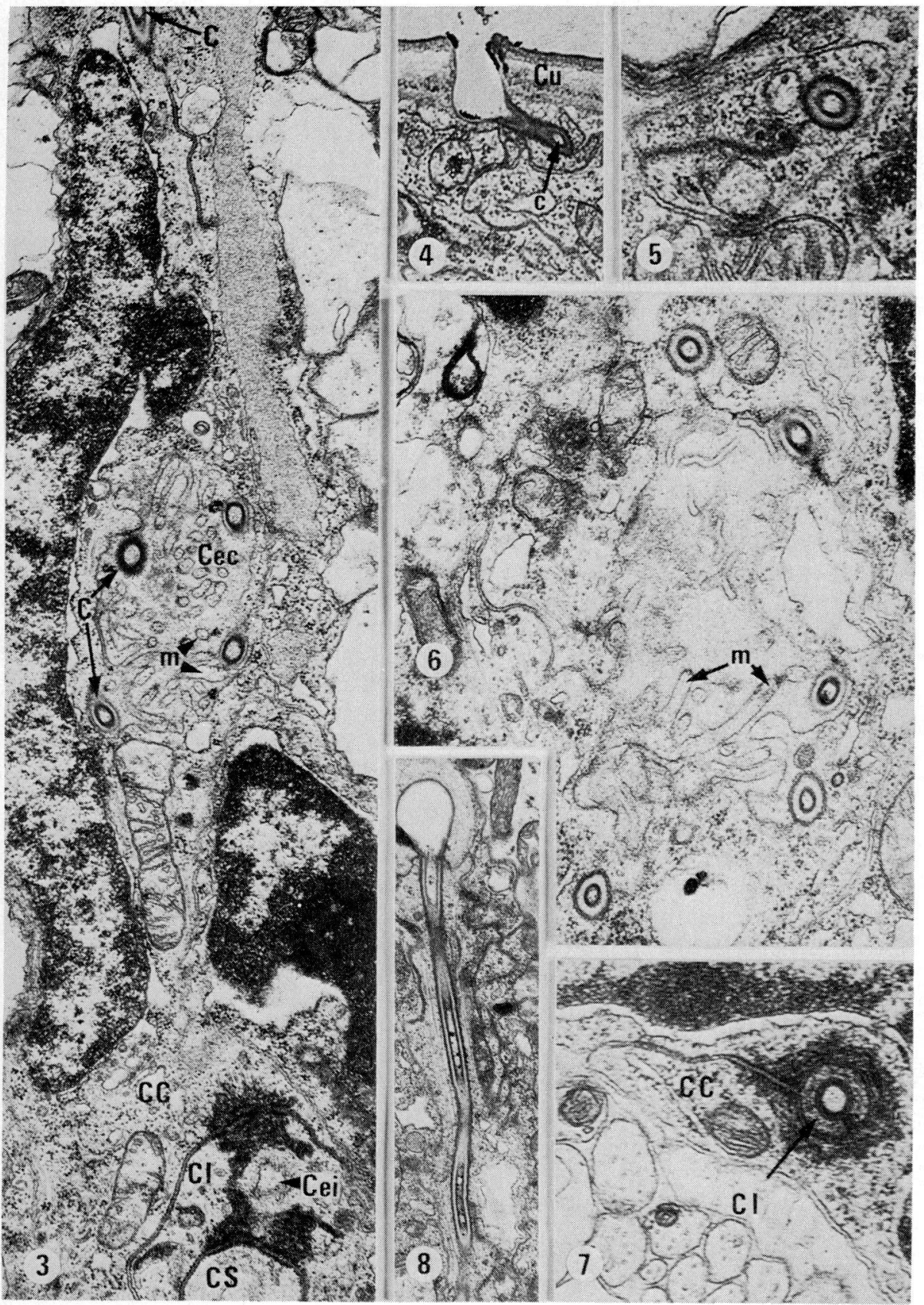


in peripheral cytoplasm and smaller ones in the whole cell; its homogeneous content is occasionally electron dense. Numerous free ribosomes are present.

The mitochondria are always small; they do not exceed $3 \mu$ in their largest dimension.

The secretory granules represent a considerable part of the cell volume. They are spherical, various in size and can reach $2000 \mathrm{~A}^{\circ}$ in diameter (Fig. 11). They possess an heterogeneous content which evolves from the formation of the granule to its release in the extracellular cavity. At the beginning they exhibit a highly organized content. Each granule is made up of a membrane containing a fluid which is slightly electron dense and in which minute electron dense rods are disposed in several concentric layers.

A transformation of the granule will occur involving the disappearance of the rods to which small scattered granules succeed; at the same time the granule membrane seems to disappear from place to place and several granules can coalesce.

2 - Intermediary cell (Fig. 3, 7, 8). This cell rolls up and manages a cavity that opens at both ends; it is, in fact, arranged mesaxonally. It is a rather small and conic cell in which we can discern three parts. In the lower part the cell ensheaths the apical part of the secretory cell. The two cells are joined by a zonular desmosome, then a septate junction. In the middle part, the intermediary cell is narrower and its extracellular cavity which prolongs that of the secretory cell, presents a widening in its center.

The third part, the upper one, is very narrow and penetrates the next cell; at this level, the cytoplasm tapers towards the extracellular cavity which is occupied by the very basal part of the canal made up of only one thin layer of electron dense material.

The nucleus is located in the lower part of the cell; it is elongated and very electron dense. The relatively electron dense cytoplasm contains a few mitochondria and free ribosomes. Numerous microfilaments are present in the middle part of the cell; 1 . they contribute to the junction (a desmosome) of this mesaxonally arranged cell; 2 . a zonular symmetrical desmosome joins the middle part of the intermediary cell to the secretory cell; it possesses even more microfilaments in the intermediary cell than in the secretory cell; 3 . an other zonular desmosome links the middle part of the intermediary cell to the canal cell and also possesses numerous microfilaments. Therefore two rings of microfilaments surround the central cavity above and under its widening.

3 - Canal cell (Fig. 3-6). It is a $15-20 \mu$ long cell which wraps the intermediary

Fig. 9. Longitudinal section in secretory (CS), intermediary (CI) and canal cell (CC). x 20000.

Fig. 10. Longitudinal section showing the extracellular cavity (Ces) of the secretory cell (CS). $x$ 11600 .

Fig. 11. Golgi apparatus of the secretory cell. x 27500.

Fig. 12. Secretory granules of the secretory cell. x 32800 . 


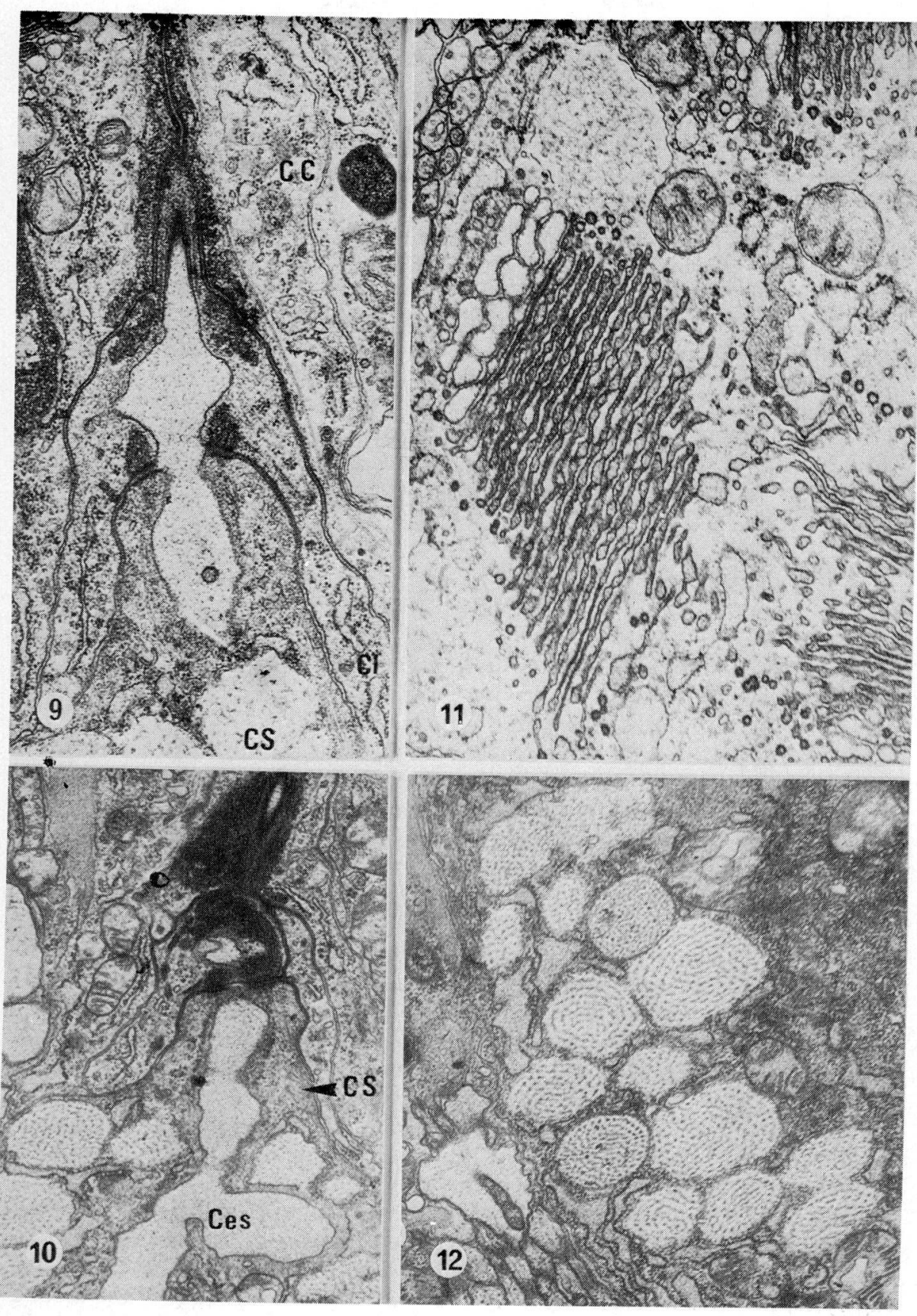


cell on almost its entire length. Its narrow upper part, enclosed in the canal cell, is joined to the latter by a hemidesmosome. A septate junction continues it around the middle part of the intermediary cell.

The canal cell is equally arranged mesaxonally with a desmosome in the outer part of its own junction strengthened with numerous microfilaments. Likewise, this cell shows an extracellular cavity where the canal is situated. This cavity is very straight at the beginning and at the end of its course. Between these two parts it enlarges, its wall shrivels into deep infoldings and microvilli between which the canal crinkles along. A granular material is present around the canal and in the lumen of the cavity. The canal is about $20 \mu$ long, $0.2 \mu$ in diameter and epicuticular in nature: it is composed of 3 layers, two external electron dense ones and an internal electron lucent one. It joins the epicuticule of the tegument at the bottom of the cuticular cavity. This last is a cylindrical hollow about $0.5 \mu$ in diameter.

The canal cell widens in its basal part where the nucleus is located which is very irregularly shaped. The cytoplasm possesses, besides classic cytoplasmic organelles, several Golgi apparatus from which the secretion present in the extracellular space probably rises.

\section{DISCUSSION}

The tegumental glands located in the antennulae of Antromysis juberthiei are present at the rate of one in every two antennular articles. Similar glands are probably present in other parts of the body.

In the $\mathrm{C}$ period each of them consists of 3 cells: a secretory cell of large size, an intermediary cell without secretory characters and a canal cell probably secretory in nature. Some prominent morphological features must be pointed out: the canal.cell possesses an extracellular cavity with microvilli, between which the canal meanders; the canal cell joins with the intermediary cell by means of a desmosome and a hemidesmosome heavily provided with microfilaments; the secretory granules have an organized content before their release in the extracellular cavity of the secretory cell.

Among the described glands in Crustacea, the tegumental glands of the antennulae of $A$. juberthiei may be compared to those possessing one secretory cell. Such glands, the lobed glands, occur in the uropods and epimeres of Porcellio pictus (Radu et al., Gorvett, Patané) and also in the basal segment of the antennae (Radu et al.). The harpacticoid copepods have numerous glands; among them, Diarthrodes cystoecus possesses about 82 paired and 18 unpaired glands practivally all of which are unicellar (Fahrenbach). The metameric glands of the Mystacocarid Derocheilocaris remani are in the same manner, unicellular (Pochon-Masson et al.). Most other glands in Crustaceans exhibit a cluster of secretory cells, but, according to Stephenson, the development of such glands, the rosettes in Armadillidium vulgare, correlated with the moulting cycle, involves a stage with only one secretory cell: the cells of the rosette enlarge, then some of them disintegrate until the gland consists of only one cell. 
The structure of the tegumental glands of Antromysis probably also undergoes some changes related to the moulting cycle; the canal, as we have seen, remains attached to the old cuticle and is cast off with this one at the ecdysis. The amount of microfilaments in desmosomes and hemidesmosome at the link of the intermediary cell with the two other cells may be related to this phenomenon. It will be the subject matter for a further study. As far as the secretory granules are concerned, organized granules looking like those present in the tegumental glands of Antromysis are present in the integument of crustaceans; in the fiddler crab, the intraepidermal connective tissue cells are characterized by the presence of such granules (Green et al. 1972); in Palaemon serratus, secretory cells exhibit tubule like structures packed in a paracristalline arrangement (Chassard-Bouchaud et al. 1973). The secretory granules of the metameric glands of Mystacocarid (Pochon-Masson et al.) are also highly organized. It must be pointed out that there are similar structures in secretory granules of various glands: salivary glands of Limnea stagnalis (Fain-Maurel 1969), accessory glands in males of Drosophila (Beaulaton et al. 1975, Perrin-Waldemer et al. 1974, Perotti 1971), genal glands of Campodea (Bareth et al. 1975, JuberthieJupeau et al. 1976).

The tegumental glands of Antromysis are exocrine and are present in males and females; they may have a function either in the moulting process or in the cleaning of the cuticle or in the defense against potential predators.

\section{SUMMARY}

Tegumental glands, located in the antennae of Antromysis juberthiei are present in males and females; in the antennulae each of them consists of 3 cells: a secretory cell of large size, an intermediary cell and a canal cell probably secretory in nature. The canal cell possesses an extracellular cavity with deep infoldings and microvilli between which the canal crinkles along. The intermediary cell is heavily provided with microfilaments. The secretory granules have an organized content.

\section{RESUME}

Des glandes tégumentaires localisées dans les antennes d'Antromysis juberthiei sont présentes dans les 2 sexes; dans l'antenne 1, chacune est constituée de 3 cellules: une cellule sécrétrice de grande taille, une cellule intermédiaire et une cellule du canal de nature vraisemblablement sécrétrice. La cellule du canal possède une cavité extracellulaire profonde, pourvue de microvillosités entre lesquelles le canal décrit des circonvolutions. La cellule intermédiaire est richement pourvue de microfilaments.

Les granules de sécrétion ont un contenu hétérogène contenant de petits bâtonnets denses aux électrons disposés en cercles concentriques. 


\section{REFERENCES}

BARETH, C. et JUBERTHIE-JUPEAU, L., 1975: Ultrastructure des glandes génales ventrales de Campodea sensillifera Condé et Mathieu et de C. kervillei Denis (Diplura). Int. J. Insect. Morph. and Embryol., 4, 4, 289-297.

BEAULATON, J. et PERRIN-WALDEMER, C., 1975: Contribution à l'étude de la sécrétion des paragonies de Drosophila melanogaster Meig. Ultrastructure et cytochimie des grains à microtubules. J. Microsc., 24, 91-104.

CALS, P., DELAMARE DEBOUTTEVILLE, C. et RENAUD-MORNANT, J., 1971: Caractères anatomiques des Mystacocarides (Crustacea). Etude de Derocheilocaris remanei Delamare-Deboutteville et Chappuis 1954. C. R. Acad. Sci. Paris, 272, 3154-3157.

CHASSARD-BOUCHAUD, C. et HUBERT, M. 1973. Etude ultrastructurale du tégument des Crustacés Décapodes en fonction du cycle d'intermue I. Présence de cellules sécrétrices à activité cyclique dans l'épiderme de Palaemon serratus Pennant. J. Microsc., 16, 75-86.

FAHRENBACH, W. H., 1961: The biology of a harpacticoid Copepod. La Cellule, 62, 303-376.

FAIN-MAUREL, A. M., 1969: Grains de sécrétions à microtubules dans les glandes salivaires de Limnea stagnalis L. (Gastéropode pulmoné). J. Microsc. (Paris), 8, 427-430.

GELDERD, C., 1909: Research on the digestive system of the Schizopoda. Anatomy, Histology and physiology. La Cellule, 25, 1-70.

GORVETT, H., 1946: The tegumental glands in the land Isopoda. A. The rosette glands. Quart. J. microsc. Sci., 87, 209-235.

GORVETT, H., 1951: The tegumental glands in the land Isopoda. B. The lobed glands: structures and distribution. Quart. J. microsc. Sci., 92, 275-296.

GORVETT, H., 1952: The tegumental glands in the land Isopoda. C. The lobed glands: the properties of their secretion and their mode of action. Quart. J. microsc. Sci., 93, 17-29.

GORVETT, H., 1956: Tegumental glands and terrestrial life in woodlice. Proc. Zool. Soc. London, 291-314.

GREEN, J. P. et NEFF, M. R., 1972: A survey of the fine structure of the integument of the fiddler crab. Tissue and Cell., 4, 1, 137-171.

JUBERTHIE, C., DELAMARE-DEBOUTTEVILlE, C., VIÑA, N. et AMINOT, A., 1974: Données sur les biotopes et la chimie des eaux souterraines de quelques grottes à crustacés (Mysidacés, Thermosbaenacés, Isopodes et Décapodes). Résultats des expéditions biospéologiques cubano-roumaines à Cuba. Tome 2, 41-49.

JUBERTHIE-JUPEAU, L. et CROUAU, Y., 1977: Ultrastructure des aesthetascs d'un Mysidacé souterrain anophtalme. C. R. Acad. Sc. Paris, 284, 2257-2259.

JUBERTHIE-JUPEAU, L. et BARETH, C., 1976: Ultrastructure des glandes génales dorsales de Campodea sensillifera Condé et Mathieu. Int. J. Insect. Morph. and Embryol., 5, 2, $137-$ 144.

MACCAGNO-PAULUCCI, T., 1951. Le ghiandole tegumentali degli Isopodi terrestri. Arch. Zool. Ital. 26, 147-166.

MESSNER, B., 1963: Ein morphologisch-histologischer Beitrag zur Häutung von Porcellio scaber Latr. und Oniscus asellus L. (Isopodia terrestria). Crustaceana, 9, 285-302.

PARK, T. S., 1966: The biology of a Calanoid Copepod Epilabidocera amphitrites Mc Murrich. La Cellule, 66, 129-251.

PATANE, L., 1955: Su alcuni complessi ghiandolari degli Isopodi terrestri. Atti Accad. gioenia Sci. nat. Catania, 6, 10, 27-32.

PEROTTI, E., 1971: Microtubules as components of Drosophila male paragonia secretion. An electron microscopic study, with enzymatic tests. J. Submicrosc. cytol., 3, 255-282.

PERRIN-WALDEMER, C. et BEAULATON, Y., 1974. Observations cytochimiques sur les inclusions à structures tubulaires des glandes accessoires de Drosophiles mâles. Coll. Soc. Fr. Micr. Electron. Rennes. J. Microsc., 20, 79 a.

POCHON-MASSON, J., RENAUD-MORNANT, J. et CALS, P., 1975: Contribution à la connaissance des glandes tégumentaires métamériques d'un Crustacé Méiobentique interstitiel (Crustacea, Mystacocarida). Cytologie structurale et infrastructurale. Arch. Zool. exp. gen., 116, 123-146. 
RADU, V. and CIHODARU-GHEORGHIU, M., 1942: Tegumentaldrüsen bei den Landisopoden. Ihre Struktur, Lage und Entwicklung. Ann. Sci. Univ. Jassy, 2, 28, 131-185.

STEVENSON, J. R., 1964: Development of the tegumental glands in the pillbug, Armadillidium vulgare, in relation to the moulting cycle. Transamer. Microsc. Soc., 83, 252-260. 